Vol. 1, No. 1, Juni 2020

\title{
SPEKTA
}

Jurnal Pengabdian Kepada Masyarakat : Teknologi dan Aplikasi

Journal homepage :

http://journal2.uad.ac.id/index.php/spekta

\section{DISKURSUS MANAJEMEN KONFLIK BERBASIS ORGANISASI KEMASYARAKATANPERKOTAAN DI YOGYAKARTA}

Ali Maksum*, Nur Azizah

${ }^{1}$ Hubungan International, Universitas Muhammadiyah Yogyakarta, J1. Brawijaya, Geblagan, Tamantirto, Kec. Kasihan, Bantul, Daerah Istimewa Yogyakarta, 55183, Indonesia

\section{INFO ARTIKEL}

Diterima : April, 2020

Direvisi : Mei, 2020

Disetujui : Juni, 2020

Keywords:
Religious Conflicts
Yogyakarta
Social Constructivism Theory
Conflict Management

\begin{abstract}
This article discusses the results of advocacy on conflict management based on urban community organizations, especially the organization 'Aisyiyah, Wirobrajan Branch, Yogyakarta City. This is important considering that the trend of conflict between religious organizations in Yogyakarta City shows serious concerns. This is because in a survey conducted in 2016, the conflict index for the City of Yogyakarta had the highest score, namely 1.4 compared to the other four districts. Thus, this dedication becomes important so that it is expected to reduce the level of conflict within the organization as an effort to self-retraint (restraint) in the Social Constructivism Theory initiated by Alexander Wendt. In this study, the authors conducted a survey which was divided into two periods, namely pre-test before mentoring and post-test after mentoring. As a result, an interesting trend emerged, namely an increase in understanding of governance before and after the material. The ability to internalize conflict management is influenced by several factors, one of which is urban locations that tend to have open discourses and attitudes in society.
\end{abstract}

\section{PENDAHULUAN}

Konflik horizontal berbasis isu keagamaan telah menjadi fenomena yang sangat mengkhawatirkan. Fenomena kekerasan atas nama agama sedemikian rupa telah menggejala di banyak daerah, bahkan secara eksplosif muncul di beberapa negara Timur Tengah akhir-akhir ini. Dalam pembahasan majalah Suara Muhammadiyah Edisi September 2013, konflik horizontal terkait dengan isu agama difahami sebagai salah satu ancaman paling serius dalam konteks harmoni sosial, dibandingkan dengan konflik horizontal lainnya. Hal ini terkait dengan pandangan bahwa agama sejatinya mengajarkan tata harmoni masyarakat, perdamaian, cinta kasih namun dalam manifestasinya konflik sosial berbasis agama lebih sering hadir dalam wajah kekerasan. Bahkan lebih dari itu,

\footnotetext{
* Corresponding author.

E-mail address: amaksum@gmail.com
}

https://doi.org/10.12928/J.spekta.v1i1.2640 
Vol. 1, No. 1, Juni 2020

konflik horizontal berbasis agama seringkali melibatkan pilar-pilar penjaga moral masyarakat, seperti tokoh agama dan institusi peribadatan, yang seharusnya para pemuka agama dan institusi keagamaan menjadi pilar dari harmoni sosial itu sendiri. Isu konflik horizontal berbasis agama di Yogyakarta akhir-akhir ini menunjukan eskalasi konflik sebagaimana tercermin dalam tabel berikut:

Tabel 1 Peristiwa Konflik Antar Organisasi Sosial Keagamaan di Yogyakarta

\begin{tabular}{|l|l|l|}
\hline Peristiwa Konflik & Pihak Berkonflik & Tahun \\
\hline $\begin{array}{l}\text { Konflik elit antara Muhammadiyah dan } \\
\text { Kelompok Tarbiyah (pengajian PKS) di } \\
\text { Piyungan }\end{array}$ & $\begin{array}{l}\text { Muhammadiyah tingkat cabang } \\
\text { (kecamatan) dan kelompok } \\
\text { pengajian Tarbiyah }\end{array}$ & 2008 \\
\hline $\begin{array}{l}\text { Penolakan pembangunan Gereja di } \\
\text { Jagalan Berbah Sleman, di Trirenggo } \\
\text { Bantul, Tirto Rajayu Galur Kulon } \\
\text { Progo }\end{array}$ & $\begin{array}{l}\text { Kelompok Kristen dan } \\
\text { Masyarakat Islam }\end{array}$ & 2013 \\
\hline Penyegelan kantor Jemaah Ahmadiyah & $\begin{array}{l}\text { Front Umat Islam (FUI) dan } \\
\text { Jamaah Ahmadiyah } \\
\text { Indonesia) }\end{array}$ & 2011 \\
\hline $\begin{array}{l}\text { Penggrebekan diskusi Irshad Manji di } \\
\text { LKIS Banguntapan }\end{array}$ & $\begin{array}{l}\text { Kelompok Islam liberal dan } \\
\text { Majelis Mujahidin Indonesia }\end{array}$ & 2012 \\
\hline $\begin{array}{l}\text { Penyerangan dan pembubaran } \\
\text { pengajian Raudhatul Jannah Kasihan } \\
\text { Bantul }\end{array}$ & $\begin{array}{l}\text { Front Jihad Islam dan kelompok } \\
\text { pengajian Raudhatul Jannah }\end{array}$ & 2013 \\
\hline $\begin{array}{l}\text { Penolakan peribadatan Kristen Jawa di } \\
\text { Paliyan Gunung Kidul }\end{array}$ & $\begin{array}{l}\text { Front Umat Islam dan } \\
\text { masyarakat Kristen Jawa }\end{array}$ & 2014 \\
\hline $\begin{array}{l}\text { Penyerangan dan Pengrusakan rumah } \\
\text { untuk peribadatan di Ngaglik Sleman }\end{array}$ & $\begin{array}{l}\text { Kelompok Kristen dan } \\
\text { kelompok keagamaan Islam }\end{array}$ & 2014 \\
\hline $\begin{array}{l}\text { Penyerangan dan pengrusakan Gereja } \\
\text { di Panggukan Sleman }\end{array}$ & $\begin{array}{l}\text { Kristen dan kelompok agama } \\
\text { yang mau } \\
\text { mengidentifikasi diri (hanya } \\
\text { bergamis) }\end{array}$ & 2014 \\
\hline
\end{tabular}

Sumber: Surwandono\&Sidik Jatmika (2014).

Sejumlah fakta di atas menunjukan gejala yang perlu untuk dicermati secara lebih mendalam, untuk mengetahui penyebab timbulnya konflik, baik dari analisis faktor struktural, akselerasi, maupun dari pemicunya. Yogyakarta telah menjadi ikon provinsi budaya, pendidikan, dan toleransi. Fakta-fakta di atas cukup memprihatinkan, di mana secara kultural, Yogyakarta memiliki pilar budaya yang sangat kuat, apalagi dengan posisi Yogyakarta yang mendapatkan status keistimewaan. Secara pendidikan, Yogyakarta juga menempati indeks literasi (melek huruf) yang tinggi, dan Yogyakarta telah mendesain diri sebagai provinsi yang mengembangkan ide toleransi melalui ide pembentukan transformasi masyarakat Madinah modern. Namun, dalam konteks indeks konflik, lokasi pengabdian yang terletak di wilayah Kota Yogyakarta menunjukkan tren mengkhawatirkan sebagaimana ilustrasi di bawah ini :

\footnotetext{
* Corresponding author.

E-mail address: amaksum@gmail.com

https://doi.org/10.12928/J.spekta.v1i1.2640
} 
SPEKTA

Jurnal Pengabdian Kepada Masyarakat : Teknologi dan Aplikasi

Vol. 1, No. 1, Juni 2020

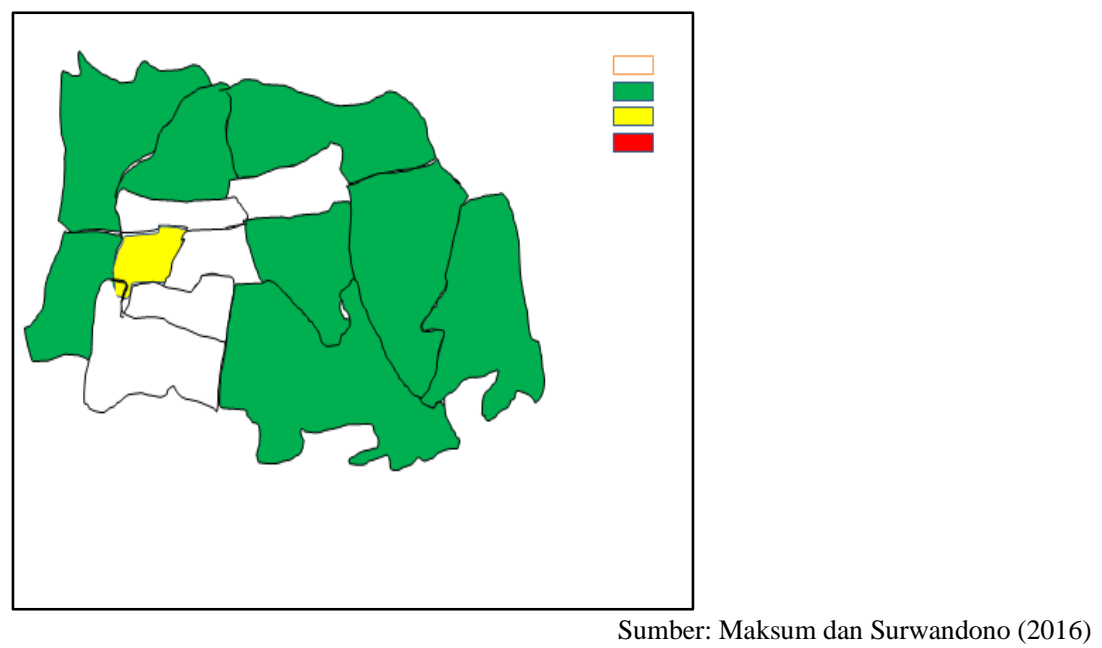

Gambar 1. Index Konflik Kota Yogyakarta

Gambar di atas menunjukkan bahwa ada satu kecamatan di Kota Yogyakarta yakni Ngampilan (berbatasan langsung dengan Kecamatan Wirobrajan) dengan angka indeks konflik di atas 3, yang bermakna konflik sudah cukup tinggi (Maksum dan Surwandono, 2016). Hal ini bermakna bahwa potensi konflik di kawasan tersebut sangat tinggi. Oleh karena itu, perlu upaya preventif untuk meminimalisir konflik salah satunya dengan upaya self-restraint untuk mengendalikan dan mengidentifikasi permasalahan sebenarnya. Sehingga, manajemen konflik menjadi keniscayaan di tengah berbagai isu dan potensi provokasi di masyarakat termasuk melalui media sosial. Lokasi Wirobrajan yang terletak di daerah urban menjadi sangat menarik karena indeks konflik tinggi di tengah masyarakat dengan tingkat pendidikan dan literasi memadai

\section{METODE PELAKSANAAN}

\section{A. Metode}

Dengan menggunakan pendekatan pelembagaan dari Peter L Berger tentang Konstruktivisme, penulis melakukan aktivitas literasi tentang tata kelola konflik social dan keagamaan, eksternalisasi khususnya di Pimpinan Cabang 'Aisyiyah Wirobrajan (PCA Wirobrajan) Yogyakarta (Berger, 2012). Aktivitas literasi dilakukan dalam bentuk ceramah dan diskusi. Sebelum penulis menyampaikan materi tentang manajemen konflik, peserta diberikan pre-test terkait materi. Kemudian, penulis melakukan sesi presentasi dan berdiskusi dengan peserta. Setelah selesai menyampaikan materi dan diskusi, penulis membagikan post-test terkait materi yang disampaikan. Dengan demikian, para peserta bisa memperoleh gambaran internalisasi khususnya tentang meningkatkan kapasitas masyarakat dalam mengelola harmoni sosial di tengah situasi kompetitif dalam mengakses sumber-sumber ekonomi, sosial, politik dan budaya dalam masyarakat yang sedang berubah. Sebelum pembahasan tentang hasil kajian, perlu disampaikan terkait gambaran umum tempat pengabdian yaitu Wirobrajan.

\footnotetext{
* Corresponding author.

E-mail address: amaksum@gmail.com

https://doi.org/10.12928/J.spekta.v1i1.2640
} 
Vol. 1, No. 1, Juni 2020

\section{B. Mitra Pengabdian}

Wirobrajan merupakan sebuah kecamatan yang masuk dalam wilayah administrasi Kota Yogyakarta. Secara geografis, letak Kecamatan Wirobrajan berada di pinggir Kota Yogyakarta dengan batas wilayah seperti berikut.

Tabel 2. Batas Geografis Kecamatan Wirobrajan

\begin{tabular}{|l|c|l|}
\hline Batas Utara & $:$ & Kecamatan Tegalrejo, Kota Yogyakarta \\
\hline Batas Timur & $:$ & $\begin{array}{l}\text { Kecamatan Gedongtengan, Kecamatan Ngampilan, } \\
\text { Mantrijeron, Kota Yogyakarta. }\end{array}$ \\
\hline Batas Selatan & $:$ & Kecamatan Kasihan, Kabupaten Bantul \\
\hline Batas Barat & $:$ & $\begin{array}{l}\text { Kecamatan Kasihan, Kabupaten Bantul, Kecamatan } \\
\text { Tegalrejo, Kota Yogyakarta }\end{array}$ \\
\hline
\end{tabular}

Berikut peta geografi Kecamatan Wirobrajan.

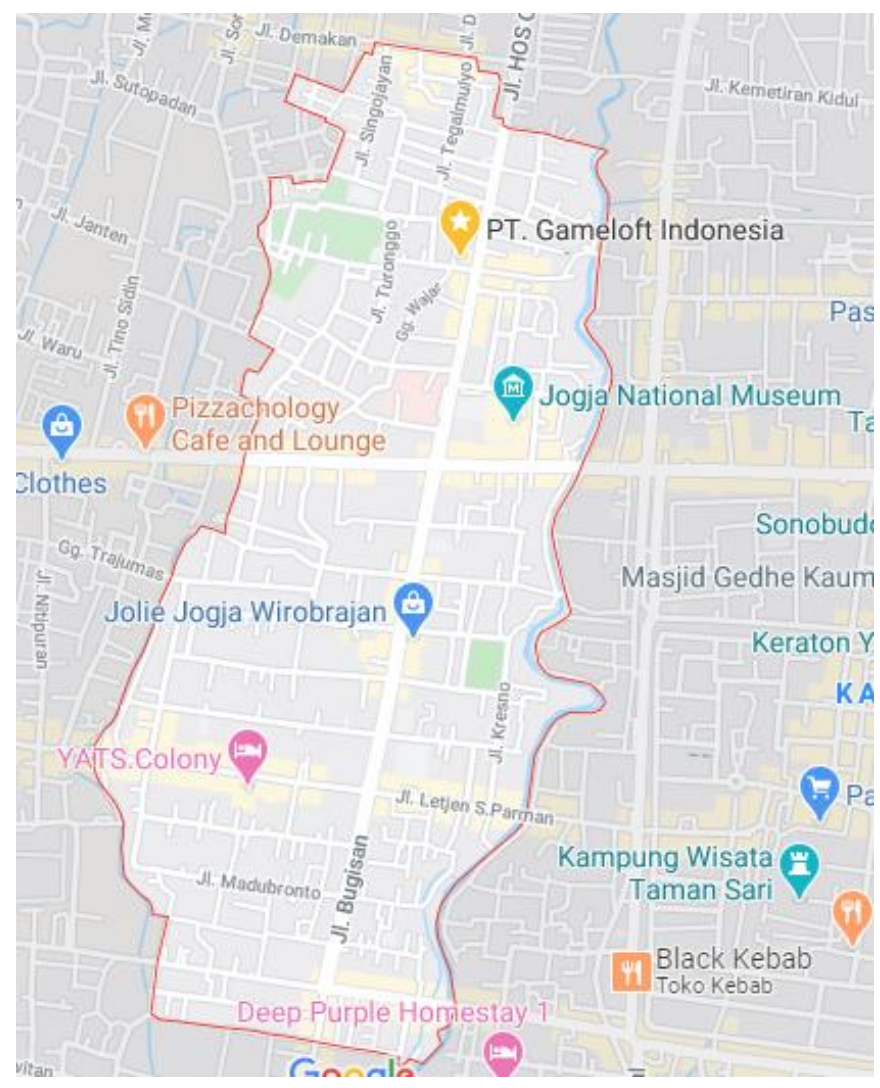

Gambar 2. Peta Kecamatan Wirobrajan

Adapun mitra pengabdian adalah PCA Wirobrajan, Kota Yogyakarta. PCA Wirobrajan adalah organisasi otonom (ortom) bagi wanita Persyarikatan Muhammadiyah yang didirikan pada 19 Mei 1917 oleh Nyai Ahmad Dahlan di Yogyarkarta. Saat ini Pimpinan Pusat 'Asiyiyah dipimpin oleh Dra. Hj. Siti Nordjannah Djohantini, M.M.,M.Si. Dalam

\footnotetext{
* Corresponding author.

E-mail address: amaksum@gmail.com

https://doi.org/10.12928/J.spekta.v1i1.2640
} 
Vol. 1, No. 1, Juni 2020

hal ini PCA Wirobrajan di bawah pembinaan Pimpinan Daerah 'Aisyiyah Kota Yogyakarta. Saat ini, PCA Wirobrajan dipimpin oleh Hj. Mar'atun Sholihah, S.S.

Wirobrajan dan PCA 'Aisyiyah, dipilih menjadi lokasi pengabdian karena dua aspek. Pertama, Kecamatan Wirobrajan lokasi di mana PCA Wirobrajan berada adalah wilayah dengan index konflik tinggi sebagaimana dijelaskan pada bagian pendahuluan. Kedua, PCA Wirobrajan adalah salah satu organisasi perkotaan penting dan mempunyai peran strategis dalam tatakelola konflik. Selain itu, dengan track record 'Aisyiyah terutama dalam pemberdayaan masyarakat menjadi penting untuk didukung dalam upaya mengelola harmonisasi di tengah masyarakat yang majemuk.

\section{HASIL DAN PEMBAHASAN}

Data yang diperoleh melalui survey (pre-test dan post-test) sekaligus pengamatan langsung mendapati temuan menarik terkait diskursus manajemen konflik khususnya peserta PCA Wirobrajan. Dari data survey yang dilakukan, tampak perbedaan signifikan antara hasil pre-test dan post-test. Persentase tentang pemahaman bagiamana menyikapi dan mengelola konflik tampak lebih tinggi pasca dilakukan penyampaian materi. Sebaliknya, sebelum dilakukan materi persentase para peserta dalam memahami cenderung rendah. Hal ini bisa dilihat pada grafik berikut.

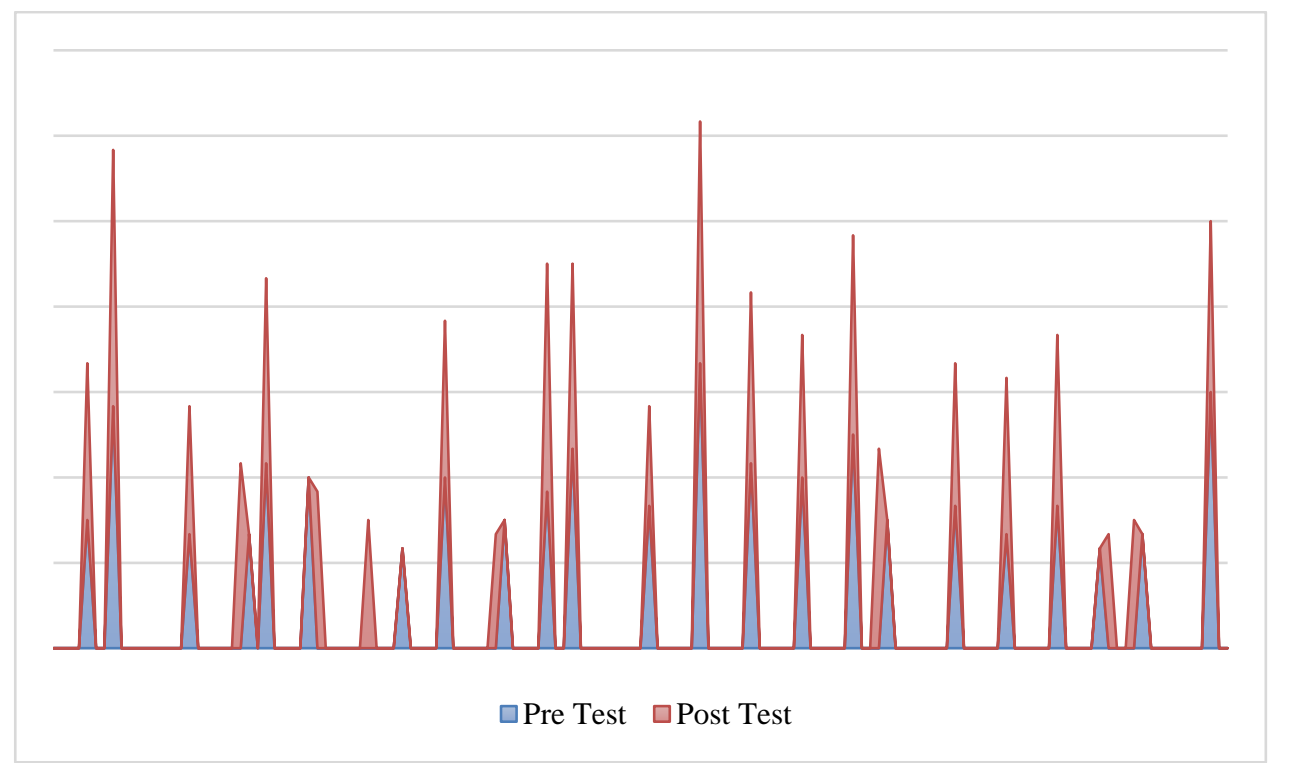

Grafik 1. Trend pemahaman tatakelola konflik PCA Wirobrajan

Sumber: data olahan

Grafik di atas menunjukkan bahwa pre-test (warna biru) terlihat lebih rendah dibanding post-test (warna oranye). Artinya bahwa internalisasi yang dilakukan selama pengabdian dengan metode ceramah dan diskusi mampu memberikan pemahaman kepada peserta tentang tatakelola konflik. Oleh karena itu, perlu dilihat lebih jauh bagaimana trend sebenarnya terkait pemahaman tatakelola konflik khususnya di kalangan anggota PCA Wirobrajan. Sebelum acara ceramah dan diskusi dimulai, peserta diberikan angket untuk diisi dengan 23 pertanyaan berbentuk skala likert. Setelah diolah, maka hasil pre-test dapat ditampilkan pada grafik berikut.

\footnotetext{
* Corresponding author.

E-mail address: amaksum@gmail.com
}

https://doi.org/10.12928/J.spekta.v1i1.2640 
SPEKTA

Jurnal Pengabdian Kepada Masyarakat : Teknologi dan Aplikasi

Vol. 1, No. 1, Juni 2020

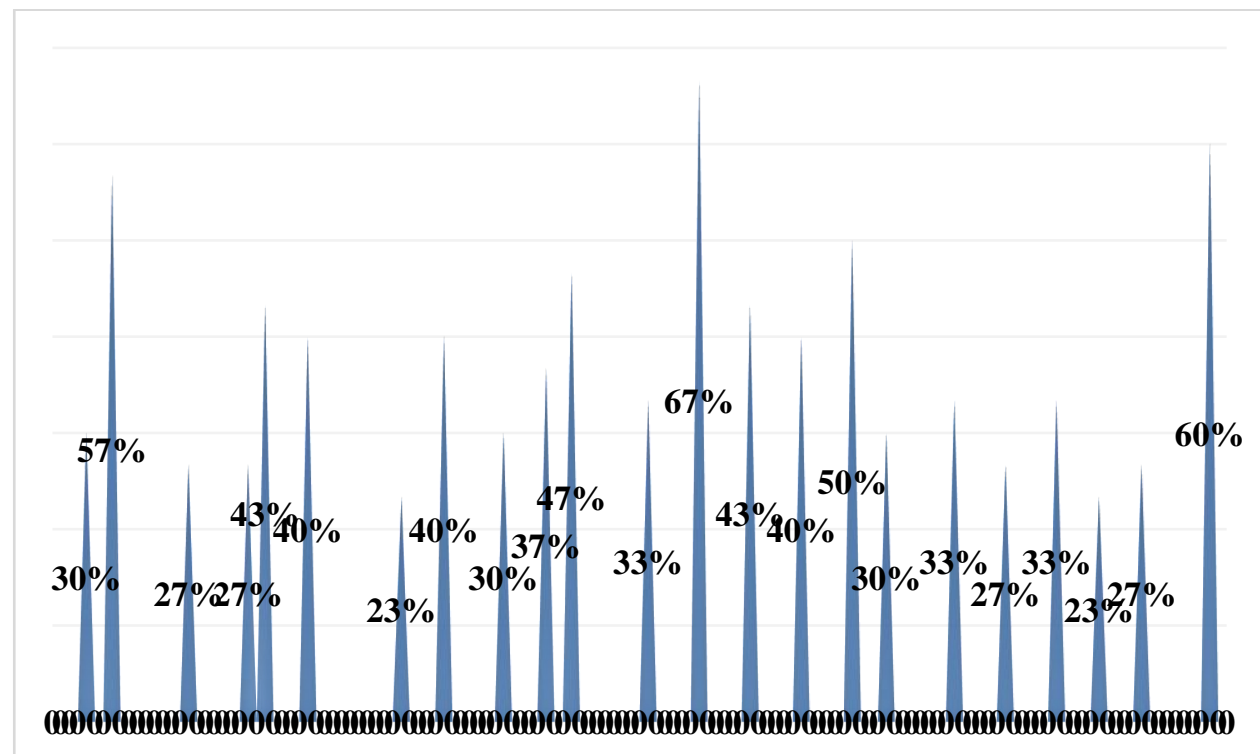

Grafik 2. Hasil pre-test pemahaman tatakelola konflik

Pada Grafik 2 di atas tampak bahwa kecenderungan peserta terkait dengan pemahaman tatakelola konflik fluktuatif. Hal ini salah satunya dipengaruhi oleh kurangnya pemahaman peserta tentang tatakelola konflik. Artinya bahwa sebelum mendengarkan pemaparan pemateri, peserta cenderung memandang konflik selalu dalam narasi negatif. Bahwa pada tingkatan tertentu, konflik memiliki sisi positif terutama dalam konteks membangun soliditas organisasi yang sangat dibutuhkan. Dari tingkat kesadaran bahwa dalam proses konflik perlu adanya sikap "mengalah" tampak cukup dikuasai peserta sebagai senjata yang penting dalam proses manajemen konflik. Ada 57\% peserta yang menyatakan bahwa konflik tidak selamanya harus berujung pada menang atau kalah. Tetapi sebaliknya ada sekitar $60 \%$ peserta yang sebelum diberikan materi menyatakan bersedia "mengalah" agar konflik tidak berkelanjutan. Demikian juga peserta juga memiliki komitmen tinggi $(50 \%)$ untuk tetap menjaga hubungan sosial terjadil harmonis. Nilai-nilai untuk mempertahankan tali silaturahmi tampak menonjol. Lebih penting lagi sebanyak $67 \%$ peserta menyatakan komitmen untuk selalu mencari penyelesaian masalah. Adapun trend selengkapnya bisa dilihat pada Grafik 3 berikut ini.

\footnotetext{
* Corresponding author.

E-mail address: amaksum@gmail.com
}

https://doi.org/10.12928/J.spekta.v1i1.2640 
Vol. 1, No. 1, Juni 2020

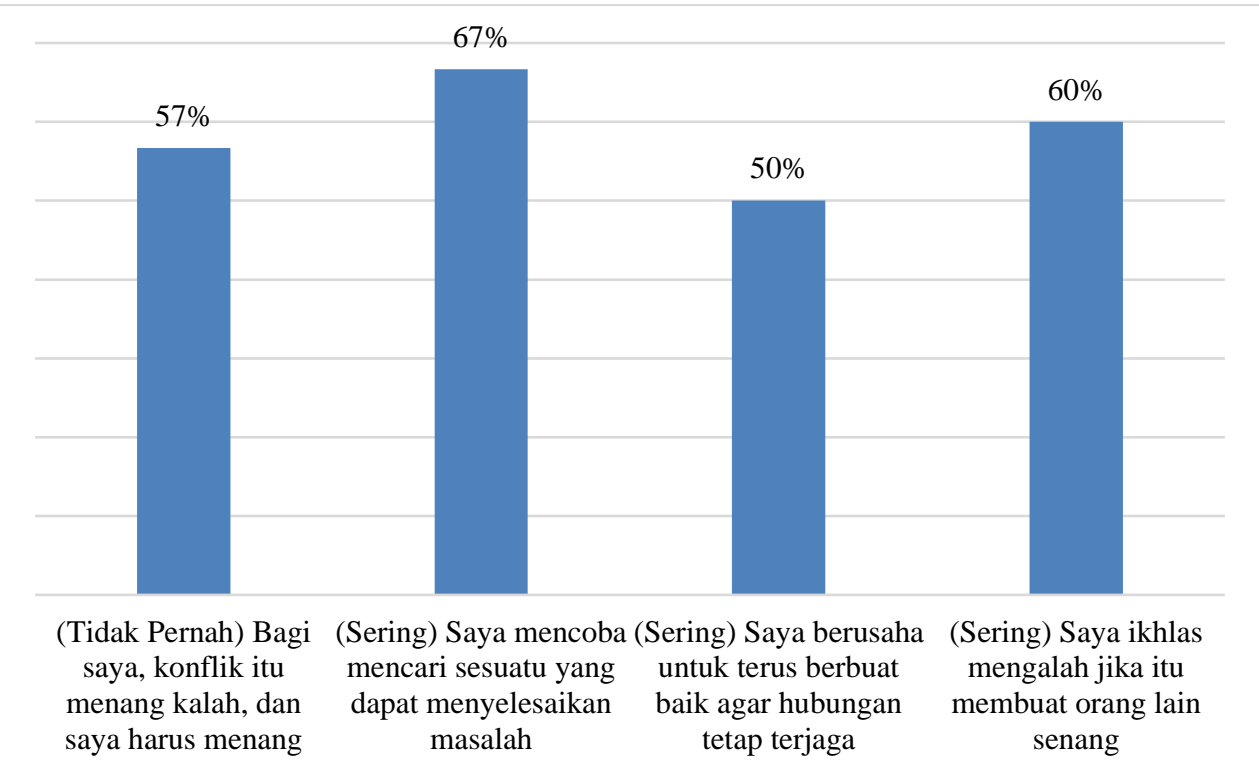

Grafik 3. Persentase pre-test tertinggi pemahaman tatakelola konflik

Sumber: data olahan

Sementara, selama pemaparan materi berlangsung tampak bahwa peserta sangat antusias dalam mengikuti materi yang disampaikan. Dalam sesi diskusi juga tampak peserta bisa langsung menghubungkan tatakelola konflik dalam konteks lingkungan sekitar tempat mereka dan organisasi PCA Wirobrajan beraktifitas. Misalnya bertanya tentang "bagaimana menyikapi terkait friksi tajam di masyarakat di tengah kontestasi Pemilihan Presiden 2019”. Ada juga yang tertarik untuk mencari permasalahan terkait dengan "ancaman" dari kemungkinan berlakunya Tindakan anarkhis para pendatang di rumah-rumah kos di wilayah Wirobrajan. Tentu sikap-sikap seperti ini harus diapresiasi karena akan sangat penting dalam mencari penyelesaian dan menata kehidupan yang lebih harmonis di lingkungan sekitar. Aspek kemajemukan masyarakat tampaknya juga disadari penuh oleh peserta bahwa hal tersebut harus dikelola dengan baik agar tidak menimbulkan konflik di masyarakat. Trend pertanyaan peserta yang sangat tertarik dengan manajemen konflik menunjukkan sebuah situasi di mana manajemen konflik sudah menjadi budaya di masyarakat. Namun, seringkali muncul ketakutan disebabkan ketidakmampuan dan ketidaktahuan bagaimana cara mengelola konflik. Justru melalui organisasi masyarakat seperti PCA Wirobrajan, peserta tampak lebih percaya diri secara berjamaah untuk menyelesaikan konflik di masyarakat. Oleh karena itu, trend pemahaman tatakelola konflik peserta cenderung meningkat. Adapun trend peningkatan pemahaman peserta pasca pemberian materi atau post-test bisa dilihat pada grafik di bawah ini.

\footnotetext{
* Corresponding author.

E-mail address: amaksum@gmail.com
}

https://doi.org/10.12928/J.spekta.v1i1.2640 
SPEKTA

Jurnal Pengabdian Kepada Masyarakat : Teknologi dan Aplikasi

Vol. 1, No. 1, Juni 2020

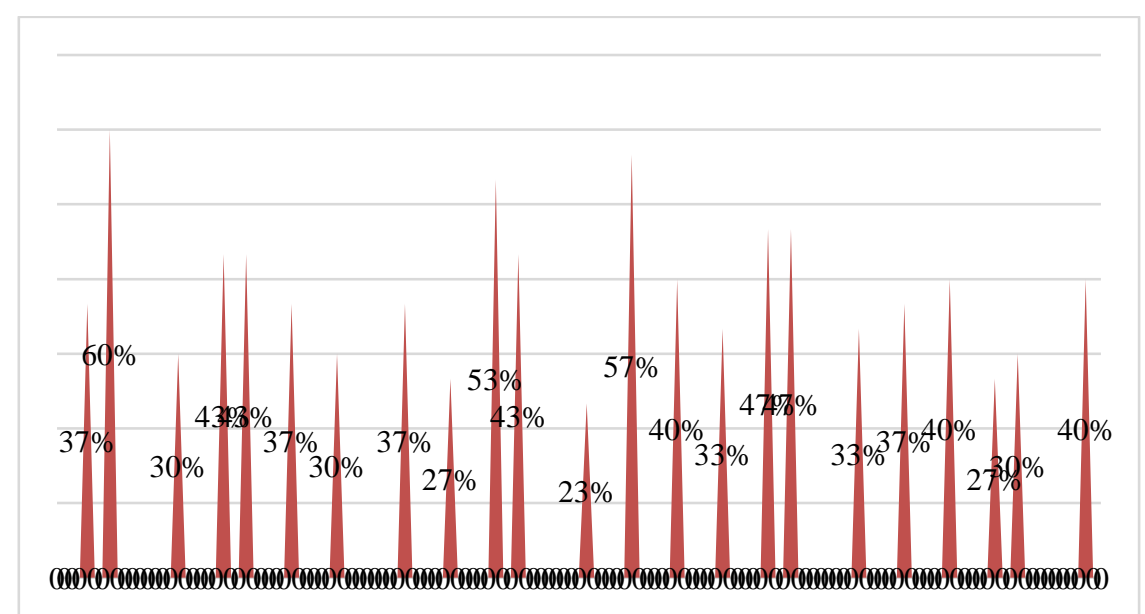

Grafik 4. Hasil post-test pemahaman tatakelola konflik

Pada Grafik 4 di atas tampak bahwa trend peningkatan terjadi pada kategori pertanyaan terkait dengan sikap "mengalah" jika terjadi konflik. Hal ini tentu sejalan dengan kultur budaya Jawa yaitu "wani ngalah luhur wekasane". Falsafah tersebut mermakna bahwa jika seseorang yang mahu mengalah bukan berarti kalah. Sebaliknya, jika seseorang mengalah justru akan mendapatkan kemulyaan. Kultur budaya Jawa yang kuat khususnya di Yogyakarta sangat penting dalam mendukung proses penyelesaian konflik dan menjadi aspek penting tatakelola konflik. Secara umum sebagaimana ditampilkan dalam Grafik 5 bahwa kecenderungan "mengalah" masih sangat tinggi (60\%). Hal ini juga konsisten dengan pre-test sebelum penyampaian materi bahwa menjaga silaturahmi dinilai lebih penting daripada berterusan terlibat dalam pusaran konflik (53\%). Selain itu, komitmen tersebut juga sejalan dengan upaya peserta untuk selalu mencari jalan penyelesaian jika terjadi konflik (57\%). Berikut tampilan Grafik 5.

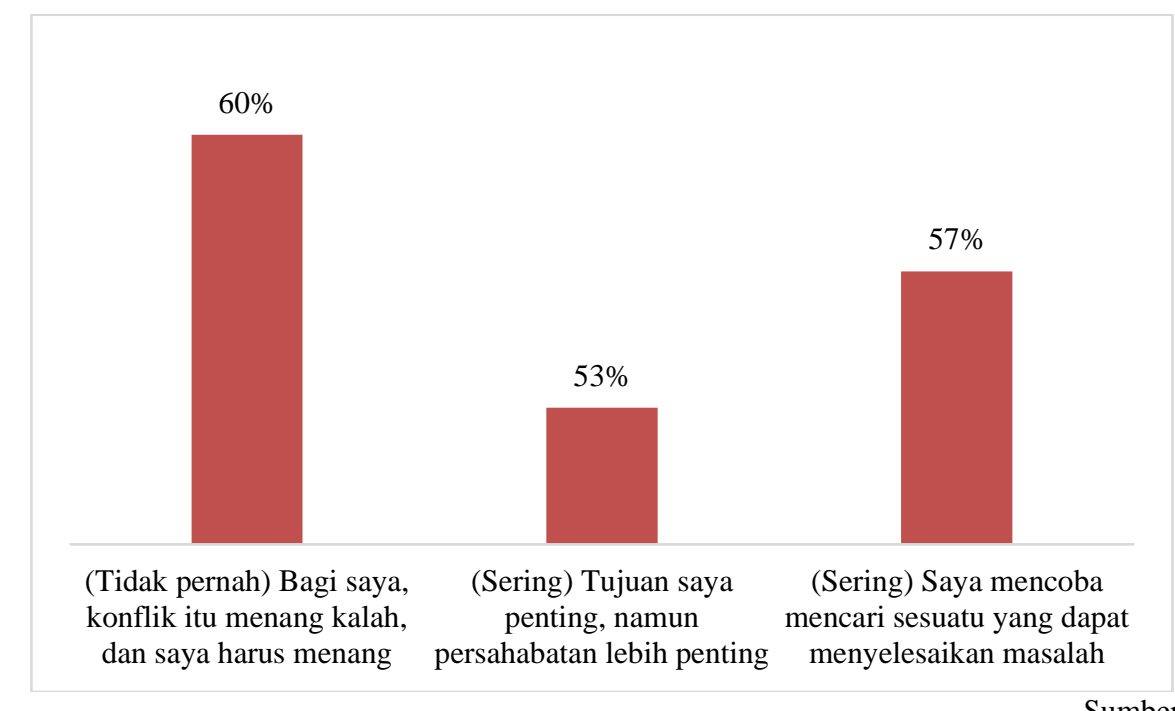

Grafik 5. Persentase post-test tertinggi pemahaman tatakelola konflik

\footnotetext{
* Corresponding author.

E-mail address: amaksum@gmail.com
}

https://doi.org/10.12928/J.spekta.v1i1.2640 
Vol. 1, No. 1, Juni 2020

Trend pemahaman tatakelola konflik tersebut juga terejawantahkan dalam upaya konkrit untuk menyelesaikan konflik di lingkungan masing-masing utamanya keluarga. Dalam sesi diskusi misalnya terungkap bahwa pada dasarnya konflik bisa dikelola dengan baik jika suasana psikologis stabil. Karena dalam keadaan psikologi stabil, maka akan mudah untuk mencari jalan keluar penyelesaian ketika terjadi konflik. Pada saat yang sama, peserta juga menyadari bahwa konflik juga memiliki nilai positif terutama berguna untuk memerkuat konsolidasi antar anggota. Dalam konteks yang lebih luas, kemampuan peserta pengabdian khususnya PCA Wirobrajan dalam mendiskursuskan selanjutnya berusaha untuk mengimplementasikan manajemen konflik dipengaruhi oleh beberapa faktor. Pertama, faktor organisasi yang sudah lama berkecimpung dalam isu di masyarakat. Kedua, faktor lokasi yang di perkotaan cenderung mempunyai wacana sosial lebih terbuka dan luas. Ketiga, faktor Pendidikan yang dimiliki para pemangku organisasi PCA Wirobrajan sangat mendukung upaya internalisasi tatakelola konflik.
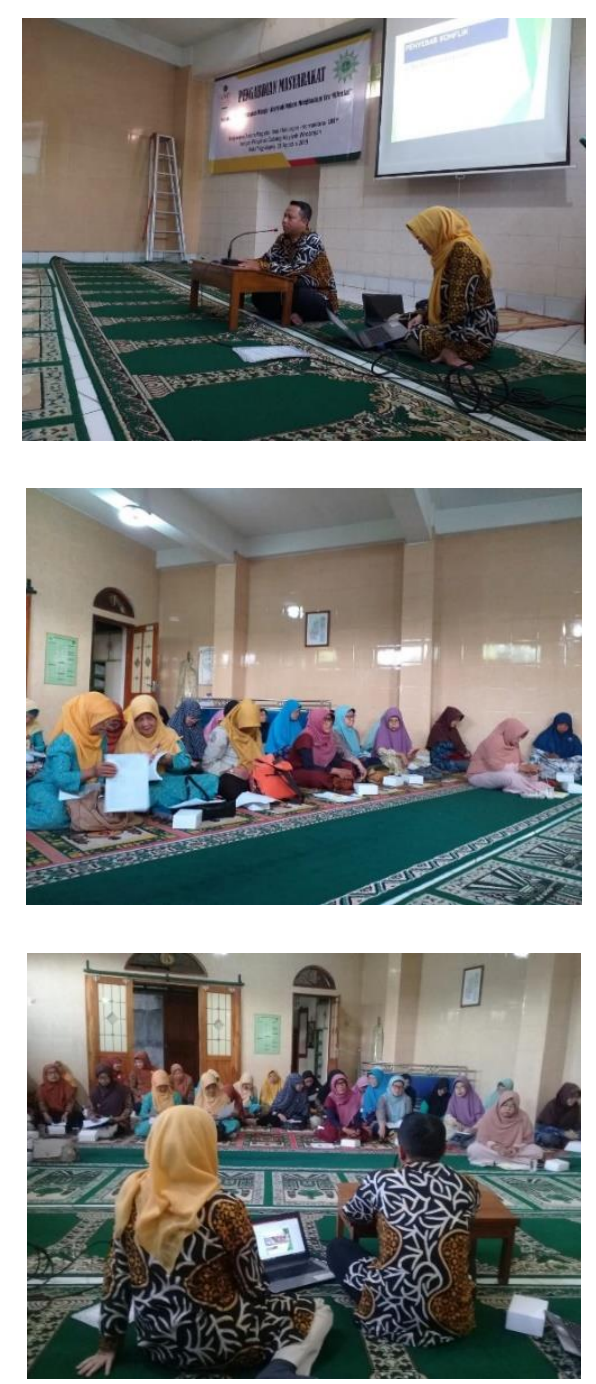

Gambar 3. Kegiatan pendampingan

Dengan demikian PCA Wirobrajan diharapkan semakin berkontribusi dalam harmonisasi masyarakat sekitar. Lebih khusus, peran penting PCA Wirobrajan selanjutnya diharapkan

\footnotetext{
* Corresponding author.

E-mail address: amaksum@gmail.com

https://doi.org/10.12928/J.spekta.v1i1.2640
} 
Vol. 1, No. 1, Juni 2020

bisa menurunkan index konflik khususnya di Kecamatan Wirobrajan, Yogyakarta. Dari semula yang mempunyai skor index konflik 3 (tiga) minimal bisa menurun ke angka 2 (dua) atau bahkan 0 (nol) berarti potensi konflik sangat rendah.

\section{KESIMPULAN}

Artikel ini menyimpulkan bahwa PCA Wirobrajan berperan penting dalam harmonisasi masyarakat di perkotaan. Hasil kajian ini menunjukkan bahwa peserta dari PCA Wirobrajan meningkat pengetahuannya terkait tatakelola konflik. Hal ini tampak dari hasil survey yang menunjukkan adanya peningkatan pemahaman tentang tatakelola sebelum dan sesudah materi. Kemampuan menginternalisasi tatakelola konflik dipengaruhi beberapa faktor salah satunya lokasi di perkotaan yang cenderung memiliki wacana dan sikap terbuka di msyarakat. Bagaimanapun, kemampuan internalisasi pengetahuan tentang tatakelola konflik sangat penting dalam proses resolusi konflik.

\section{UCAPAN TERIMA KASIH}

Penulis menyampaikan penghargaan dan terima kasih kepada Universitas Muhammadiyah Yogyakarta atas dukungan dana bagi penyelesaian pengabdian dan penulisan naskah ini. Artikel ini adalah pandangan pribadi penulis dan tidak merepresentasikan Universitas Muhammadiyah Yogyakarta.

\section{DAFTAR PUSTAKA}

Berger, P. (2012). The Anatomy of Peace. Thought, 20(4), 697-699. https://doi.org/10.5840/thought1945204158

Fischer, Dietrich. (2011). Johan Galtung: Pioneer of Peace Research. New York, Springer.

Maksum, A. dan Surwandono. (2016) Analisis Akselerasi Konflik Organisasi Keagamaan Islam Di Yogyakarta. Prosiding SENASPRO Malang.

Jung, E. (2014). Islamic organizations and electoral politics in Indonesia: The case of Muhammadiyah, Southeast Asia Research, 22(1): 73-86 5.

Masatoshi, Kisaichi. (2015). Popular Movements and Democratization in the Islamic World, New York, Routledge.

Phillips, C. and Valbjørn, M. (2018). What is in a Name?': The Role of (Different) Identities in the Multiple Proxy Wars in Syria. Small Wars and Insurgencies, 29 (3): 414433.

Pruitt, L. J. (2015). Gendering the study of children and youth in peacebuilding. Peacebuilding, 3(2), 157-170. https://doi.org/10.1080/21647259.2015.1052630

Robinson, S. (2015). Islam, Responsibility and Business in the Thought of Fethullah Gülen. Journal of Business Ethics. https://doi.org/10.1007/s10551-014-2101-3

Surwandono, Ali Maksum, S. J. (2019). An Early Warning Information System for Social and Religious Conflict in Yogyakarta, Indonesia. International Journal of Interdisciplinary Social and Community Studies, 14(1), 37-47. https://doi.org/https://doi.org/10.18848/2324-7576/CGP.

\footnotetext{
* Corresponding author.

E-mail address: amaksum@gmail.com

https://doi.org/10.12928/J.spekta.v1i1.2640
} 